\title{
Identification of microRNAs Responding to Aluminium, Cadmium and Salt Stresses in Barley Roots
}

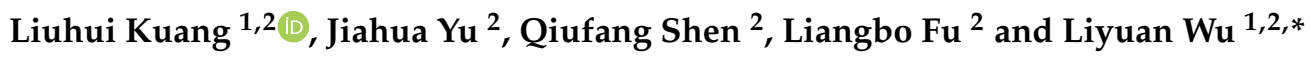 \\ 1 Department of Architectural Engineering, Yuanpei College, Shaoxing University, Shaoxing 312000, China; \\ kuangliuhui@zju.edu.cn \\ 2 Key Laboratory of Crop Germplasm Resource of Zhejiang Province, Department of Agronomy, \\ Zhejiang University, Hangzhou 310058, China; robert_jiahua@163.com (J.Y.); shenqf@zju.edu.cn (Q.S.); \\ fulb@zju.edu.cn (L.F.) \\ * Correspondence: address: wuly@zju.edu.cn
}

check for updates

Citation: Kuang, L.; Yu, J.; Shen, Q.; Fu, L.; Wu, L. Identification of microRNAs Responding to

Aluminium, Cadmium and Salt Stresses in Barley Roots. Plants 2021, 10, 2754. https://doi.org/10.3390/ plants10122754

Academic Editors: Pirjo Mäkelä,

Mercè Llugany, Peter A. Roussos and Mumtaz Cheema

Received: 11 November 2021 Accepted: 9 December 2021

Published: 14 December 2021

Publisher's Note: MDPI stays neutral with regard to jurisdictional claims in published maps and institutional affiliations.

Copyright: (c) 2021 by the authors. Licensee MDPI, Basel, Switzerland. This article is an open access article distributed under the terms and conditions of the Creative Commons Attribution (CC BY) license (https:/ / creativecommons.org/licenses/by/ $4.0 /)$.

\begin{abstract}
Plants are frequently exposed to various abiotic stresses, including aluminum, cadmium and salinity stress. Barley (Hordeum vulgare) displays wide genetic diversity in its tolerance to various abiotic stresses. In this study, small RNA and degradome libraries from the roots of a barley cultivar, Golden Promise, treated with aluminum, cadmium and salt or controls were constructed to understand the molecular mechanisms of microRNAs in regulating tolerance to these stresses. A total of 525 microRNAs including 198 known and 327 novel members were identified through high-throughput sequencing. Among these, 31 microRNAs in 17 families were responsive to these stresses, and Gene Ontology (GO) analysis revealed that their targeting genes were mostly highlighted as transcription factors. Furthermore, five (miR166a, miR166a-3p, miR167b-5p, miR172b-3p and miR390), four (MIR159a, miR160a, miR172b-5p and miR393) and three (miR156a, miR156d and miR171a-3p) microRNAs were specifically responsive to aluminum, cadmium and salt stress, respectively. Six miRNAs, i.e., miR156b, miR166a-5p, miR169a, miR171a-5p, miR394 and miR396e, were involved in the responses to the three stresses, with different expression patterns. A model of microRNAs responding to aluminum, cadmium and salt stresses was proposed, which may be helpful in comprehensively understanding the mechanisms of microRNAs in regulating stress tolerance in barley.
\end{abstract}

Keywords: abiotic stresses; microRNA; barley; target genes; aluminum; cadmium; salinity

\section{Introduction}

Abiotic stresses such as salinity, heavy metals and aluminum (Al) in soil severely limit crop production worldwide, with estimated losses of over USD 120 billion p.a. [1]. At present, nearly $50 \%$ of the world's potential arable lands are acidic, and Al toxicity is a primary factor affecting crop growth in acid soil [2]. $\mathrm{Al}$ (mainly in the form of $\mathrm{Al}^{3+}$ in acidic soil) is toxic to plant growth by targeting various cellular sites and processes, which leads to the inhibition of root elongation and the uptake of water and nutrients [2-4]. Heavy metal contamination in soil, mainly due to unwise industry activities and the application of metal-containing fertilizers, has raised a severe threat to crop production and food safety [5]. Cadmium (Cd) is commonly considered one of the most widespread and dangerous heavy metals. Cd stress not only inhibits plant growth and development, leading to reduced yield, but also causes the potential damage to human health through the food chain [6]. Moreover, soil salinization is also a major abiotic factor affecting crop planting and production worldwide [7]. Currently, over 900 million hectares of soil have been affected by salinity worldwide, which is becoming a bottleneck of sustainable development for agriculture [7].

Barley (Hordeum vulgare) is an important cereal crop, ranking fourth in terms of planting area in the world, and it is characterized by wider adaptation and higher salt 
tolerance when compared to other cereal crops [8,9]. Actually, barley also shows wide genetic variation in its tolerance to $\mathrm{Al}$ and $\mathrm{Cd}$ toxicity $[10,11]$. Moreover, barley is an excellent model crop in physiological and molecular studies, especially for the mechanisms of tolerance to various stresses in plants.

Over the past few years, more and more studies have been focused on efficient and precise gene regulation mediated by microRNAs (miRNAs). miRNAs are endogenous noncoding RNA molecules with approximately 20-24 nucleotides (nt) in length, which bind with target mRNA sequences through complementary base pairing, leading to the cleavage of target genes [12]. Currently, 7057 miRNAs have been identified in 73 plant species (http:/ / www.mirbase.org, accessed on 08 January 2019). It is well known that miRNAs play diverse roles in many intracellular activities, including development, metabolism and stress defense [12]. For instance, osa-miR393 is associated with primary and crown root growth in rice [13] and miR172-guided HvAPETALA2 (HvAP2) mRNA cleavage determines the cleistogamous flowering and grain density in barley $[14,15]$. Furthermore, over-expression of miR393 increases the sensitivity to salt and drought stresses due to the reduced expression of the target genes OsTIR1 (transport inhibitor response 1) and OsAFB2 (auxin-signaling F-box 2) in rice [16]. Transgenic rice and Arabidopsis thaliana plants constitutively over-expressing osaMIR396c have shown reduced salt and alkali stress tolerance [17]. Similarly, miRNAs are also involved in the responses to heavy metals such as chromium (Cr) and Cd [18,19]. Over-expression of miR166 in rice could decrease $\mathrm{Cd}$ translocation from roots to shoots and accumulation in grains, and enhance $\mathrm{Cd}$ tolerance through regulating the target gene OsHB4 (homeodomain-containing protein) [19]. Moreover, miRNAs involved in the response to $\mathrm{Cd}, \mathrm{Al}$ or salt stress have been identified in cultivated and wild barley [20-22]. However, all of the previous studies were focused on the functioning of miRNAs in regulating gene expression under a specific abiotic stress, and little research has been carried out on miRNA-mediated gene networks in plants under multiple abiotic stresses, which occurs frequently for field crops.

In this study, a barley cultivar, Golden Promise, which is widely used in genetic transformation, was treated with or without $\mathrm{Al}, \mathrm{Cd}$ or salt stress. Small RNA libraries were developed to identify miRNAs responding to single or multiple stresses and degradome sequencing was performed to discover their target genes. We hypothesized that these differently expressed miRNAs and their targets played significant roles in tolerance to $\mathrm{Al}, \mathrm{Cd}$ and salt stresses in barley. These identified specific miRNAs could be useful for breeding new barley cultivars with high tolerance to abiotic stresses.

\section{Results}

\subsection{Identification of Conserved and Novel miRNAs in Golden Promise}

The root growth of the barley cultivar Golden Promise was dramatically inhibited under $\mathrm{Al}, \mathrm{Cd}$ and salt stress treatments in comparison with controls (Figure 1a-c). In order to identify miRNAs responding to the three stresses, 12 small RNA libraries were prepared and sequenced. The clean reads were BLASTN-searched in miRBase to identify the conserved and novel miRNAs. As a result, a total of 525 miRNAs were detected, including 198 known miRNAs, 94 new members of known miRNAs and 233 potential candidate miRNAs. Of these, miRNAs of $21 \mathrm{nt}$ in length were most dominant (Figure 2a). The majority of miRNAs with lengths of 18-22 nt started with a $5^{\prime} \mathrm{U}$ whereas the first nucleotide was A base for most 24-25 nt miRNAs (Figure 2b).

According to the BLASTN search results, 246 miRNAs were categorized into 47 known miRNA families (Figure 3). There was a large variation in the members of each miRNA family, with 11 conserved families, such as MIR156, MIR166 and MIR167_1, containing more than 10 miRNA members. Moreover, there were 16 families which consisted of only one member, such as MIR394, MIR528, MIR8005, and so on. 


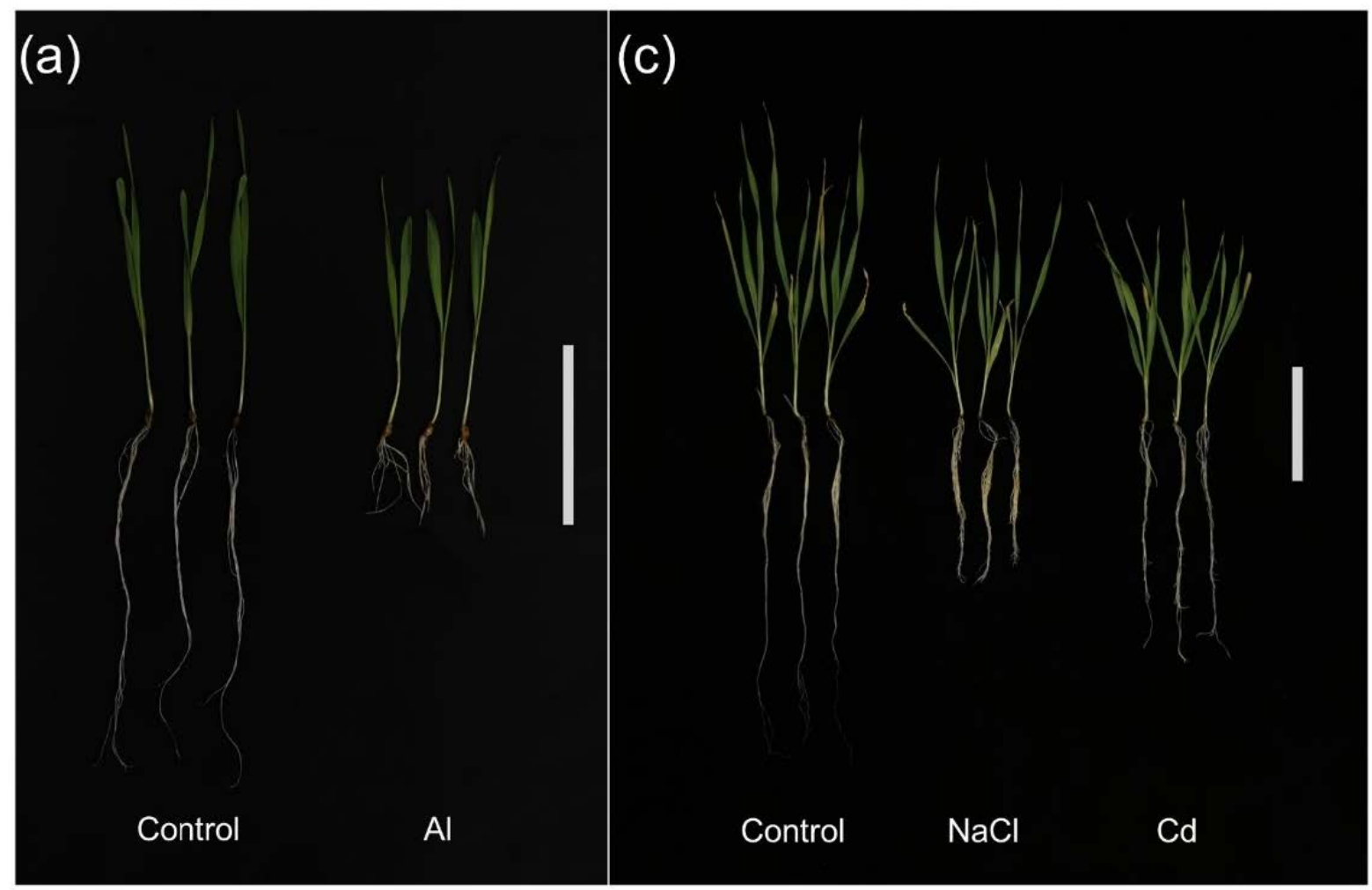

(b)

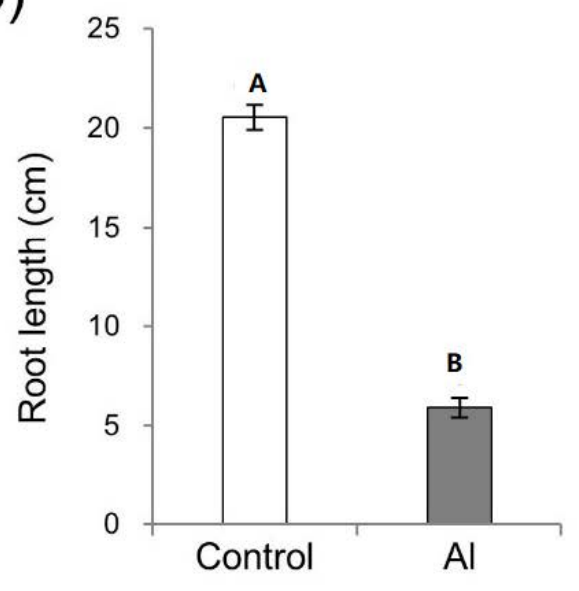

(d)

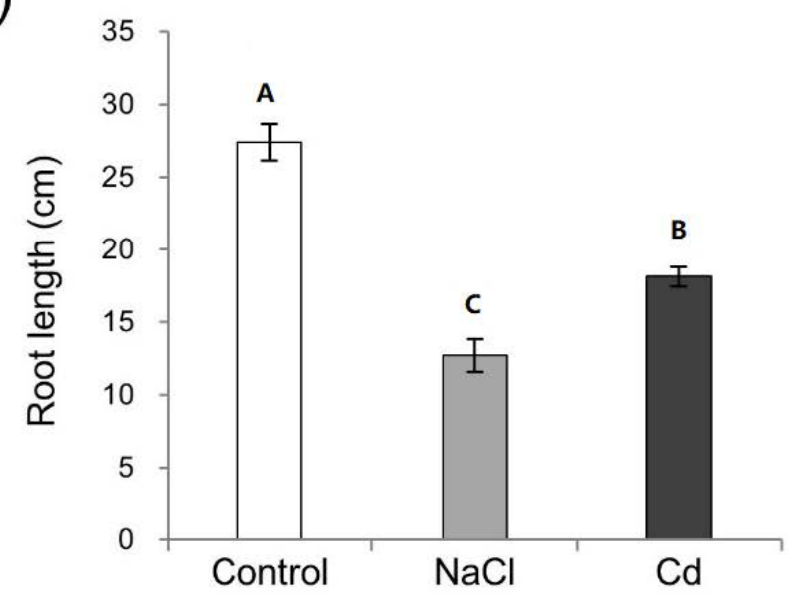

Figure 1. The root growth of the barley cultivar Golden Promise under different conditions. Three-day-old seedlings were exposed to $10 \mu \mathrm{M} \mathrm{AlCl}_{3}$ for 10 days (a,b). Twelve-day-old seedlings were treated with $5 \mu \mathrm{M} \mathrm{CdCl}_{2}$ and $200 \mathrm{mM} \mathrm{NaCl}$ $(\mathbf{c}, \mathbf{d})$ or control conditions for 10 days, respectively. Bar $=10 \mathrm{~cm}$. Data are means $\pm S D(n=6)$, and significant difference $(p<0.05)$, compared via Tukey's HSD test.

\subsection{Identification of miRNAs Responding to Al, Cd and Salt Stresses}

The miRNAs with fold-changes of larger than 0.5 were considered to be differentially expressed miRNAs under stress conditions. A total of 31 differentially expressed miRNAs were found in barley roots in response to one, two or all of three stresses (Table 1 and Figure S1). Among these, five miRNAs were upregulated and 12 were downregulated in response to $\mathrm{Al}$ stress. Under $\mathrm{Cd}$ stress, 13 miRNAs were upregulated and seven were downregulated. Under salt stress, seven and 11 miRNAs were up- and downregulated, respectively. Furthermore, 12 miRNAs specifically responded to only one stress. For example, ata-miR156a-3p and ata-miR156d-3p were specifically responsive to salt stress. Under Al stress, hvu-miR166a and ata-miR166a-3p were specifically depressed. The miRNA 
hvu-MIR159a-5p was upregulated and ata-miR160a-5p was downregulated under Cd stress. In total, there were 12 miRNAs responding commonly to two stresses. For instance, ata-miR169c-5p, ata-miR169c-5p and osa-miR319a-3p.2-3p were remarkably upregulated under both $\mathrm{Cd}$ and salt stresses. In addition, there were six miRNAs which responded commonly to all of three stresses, including ata-miR156b-3p, ata-miR166a-5p, ata-miR169a$3 p$, ata-miR171a-5p, ata-miR394-5p and ata-miR396e-5p. However, most of these multiple stresses-responsive miRNAs differed in the expression pattern under the different stresses. For example, miR171a and miR394 were significantly upregulated when exposed to $\mathrm{Cd}$ toxicity, but were obviously downregulated under $\mathrm{Al}$ and salt stress. Only the miRNA ata-miR156b-3p showed the same expression pattern in responding to the three stresses (Table 1 and Figure S1).

(a)

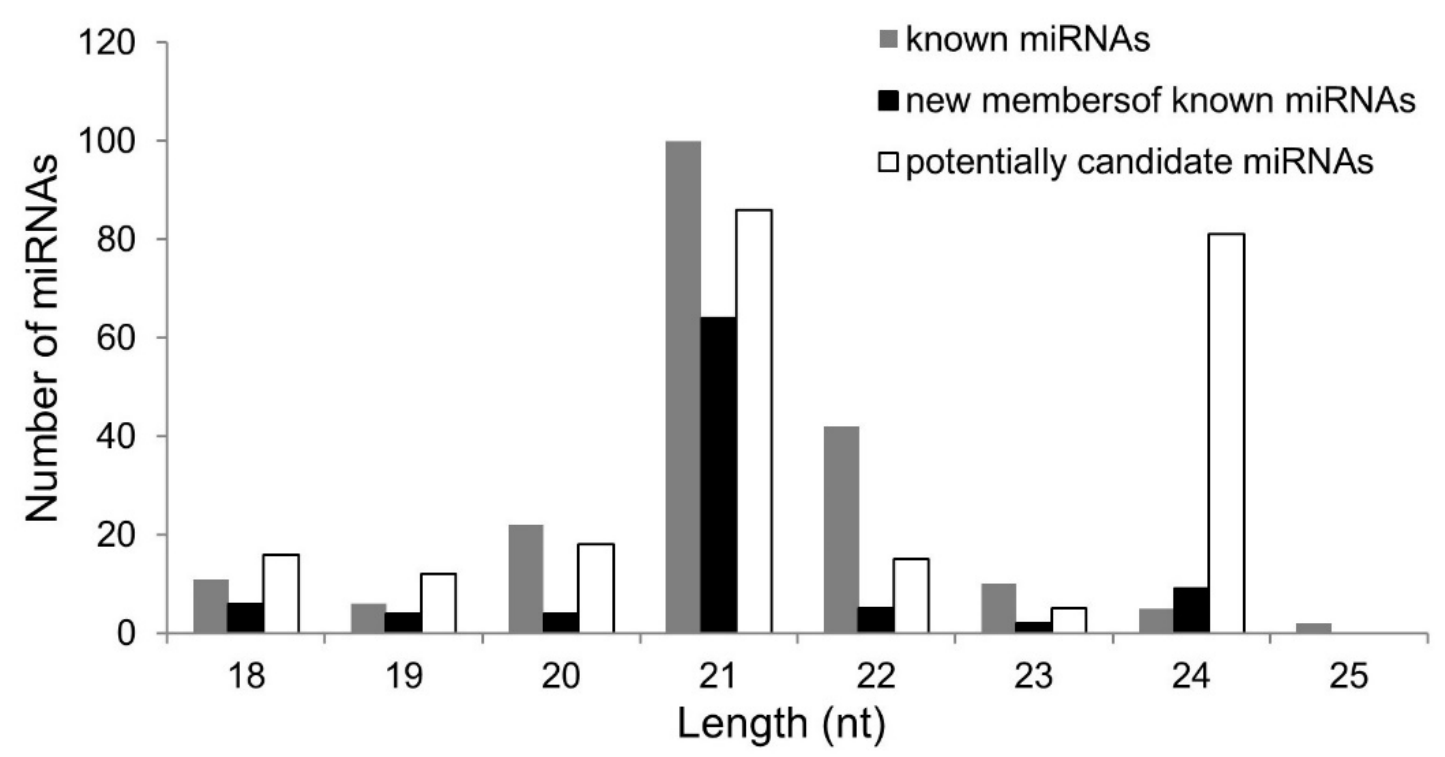

(b)

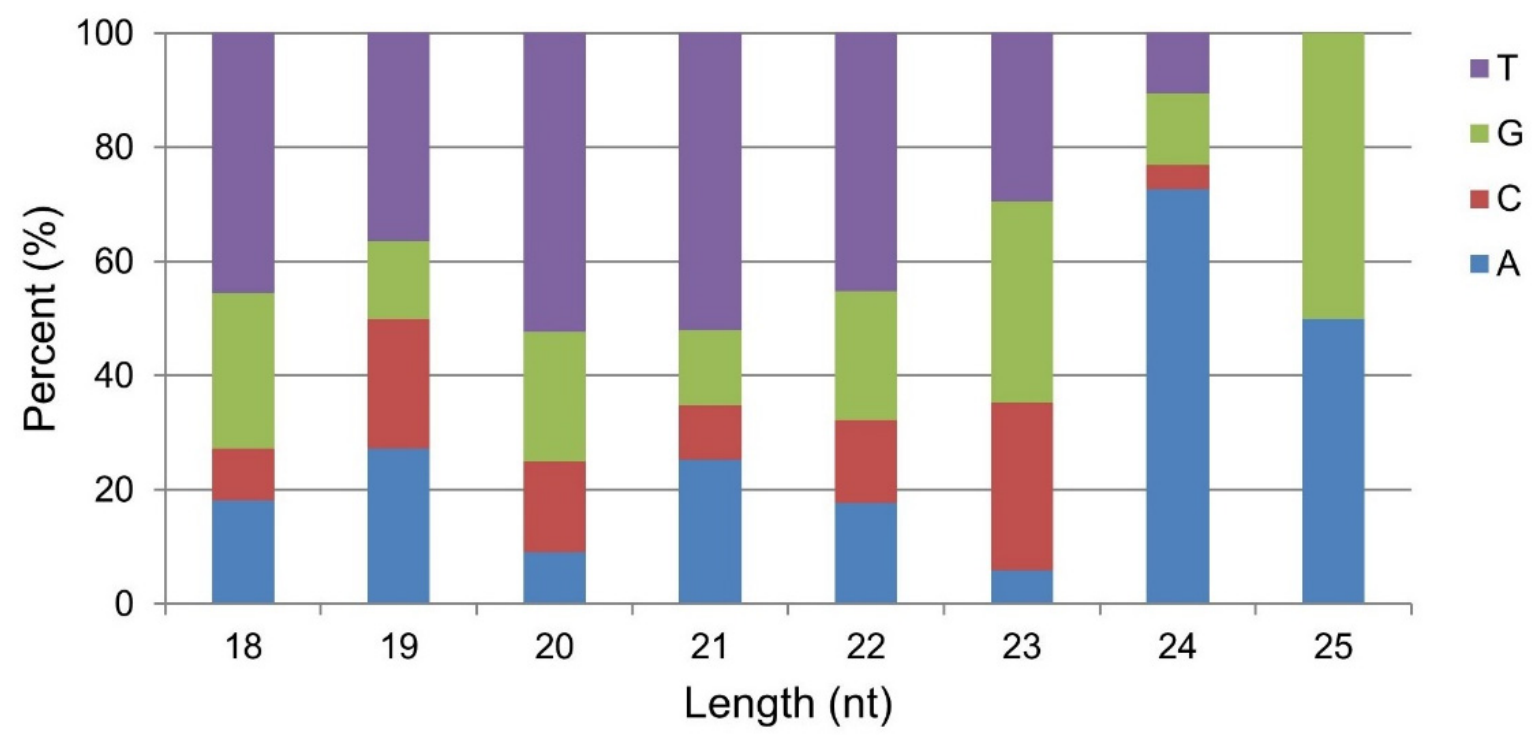

Figure 2. Overview of miRNAs identified in barley roots. (a) Length distribution of miRNAs in three classes. (b) The prevalence of first nucleotide bias in miRNAs with different lengths. 


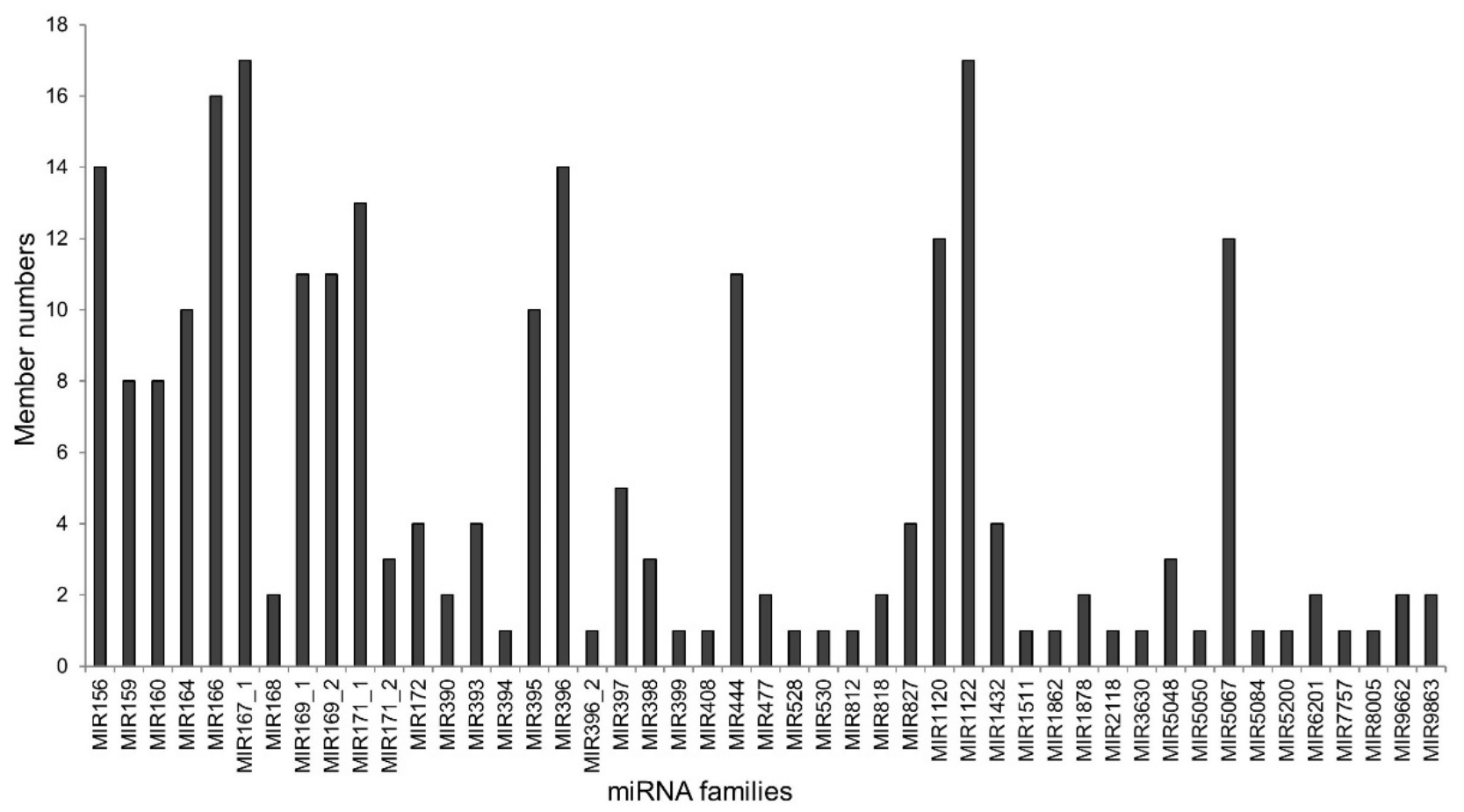

Figure 3. Member numbers of miRNA families.

Table 1. Differentially expressed miRNAs in response to $\mathrm{Al}, \mathrm{Cd}$ and salt stresses in barley roots.

\begin{tabular}{|c|c|c|c|c|c|c|}
\hline miRNA Name & $\mathrm{Al}^{\mathrm{a}}$ & $\mathrm{Cd}^{\mathrm{b}}$ & Salt ${ }^{c}$ & Target Rranscript & Annotation & $\begin{array}{l}\text { Degradome } \\
\text { Detection }^{d}\end{array}$ \\
\hline \multirow[t]{2}{*}{ ata-miR156a-3p } & \multirow[t]{2}{*}{0.20} & \multirow[t]{2}{*}{0.05} & \multirow[t]{2}{*}{0.85} & HORVU3Hr1G072810.1 & Gibberellin 2-oxidase & + \\
\hline & & & & HORVU1Hr1G078160.1 & $\begin{array}{l}\text { P-loop containing nucleoside } \\
\text { triphosphate hydrolases } \\
\text { superfamily }\end{array}$ & + \\
\hline ata-miR156b-3p & 1.15 & 0.71 & 1.95 & HORVU6Hr1G028980.8 & Cinnamoyl coa reductase 1 & - \\
\hline ata-miR156d-3p & -0.10 & 0.35 & 1.26 & HORVU5Hr1G042740.2 & $\begin{array}{l}\text { UDP-Glycosyltransferase } \\
\text { superfamily }\end{array}$ & + \\
\hline hvu-MIR159a-5p & -0.44 & 0.56 & 0.38 & HORVU1Hr1G088510.1 & Mitogen-activated protein kinase 16 & - \\
\hline \multirow[t]{2}{*}{ osa-miR319a-3p.2-3p } & \multirow{2}{*}{-0.35} & \multirow[t]{2}{*}{1.79} & \multirow[t]{2}{*}{1.09} & HORVU2Hr1G060120.1 & TCP4 & + \\
\hline & & & & HORVU5Hr1G103400.1 & $\mathrm{TCP} 4$ & + \\
\hline \multirow[t]{5}{*}{ ata-miR160a-5p } & \multirow{5}{*}{-0.44} & \multirow{5}{*}{-0.65} & \multirow{5}{*}{-0.20} & HORVU2Hr1G089670.2 & ARF10 & + \\
\hline & & & & HORVU2Hr1G089660.7 & ARF10 & + \\
\hline & & & & HORVU7Hr1G101270.6 & ARF16 & + \\
\hline & & & & HORVU6Hr1G026750.1 & ARF18 & + \\
\hline & & & & HORVU1Hr1G041770.6 & ARF22 & + \\
\hline \multirow[t]{4}{*}{ ata-miR164a-5p } & \multirow{4}{*}{-0.39} & \multirow[t]{4}{*}{-1.32} & \multirow{4}{*}{-1.13} & HORVU2Hr1G080460.8 & NAC domain protein & + \\
\hline & & & & HORVU7Hr1G072670.3 & NAC domain containing protein 1 & + \\
\hline & & & & HORVU5Hr1G011650.2 & NAC domain containing protein 1 & + \\
\hline & & & & HORVU5Hr1G041400.1 & Phytosulfokine 2 & + \\
\hline \multirow[t]{4}{*}{ hvu-miR166a } & \multirow{4}{*}{-0.82} & \multirow[t]{4}{*}{0.30} & \multirow[t]{4}{*}{0.01} & HORVU5Hr1G010650.1 & Homeobox-leucine zipper family & + \\
\hline & & & & HORVU5Hr1G061410.29 & Homeobox-leucine zipper HOX10 & + \\
\hline & & & & HORVU0Hr1G010250.3 & Homeobox-leucine zipper HOX32 & + \\
\hline & & & & HORVU1Hr1G041790.2 & Homeobox-leucine zipper family & + \\
\hline \multirow[t]{2}{*}{ ata-miR166a-3p } & \multirow[t]{2}{*}{-0.54} & \multirow[t]{2}{*}{0.06} & \multirow[t]{2}{*}{0.22} & HORVU1Hr1G041790.2 & Homeobox-leucine zipper family & + \\
\hline & & & & HORVU5Hr1G010650.1 & Homeobox-leucine zipper family & + \\
\hline \multirow[t]{2}{*}{ ata-miR166a-5p } & \multirow[t]{2}{*}{-0.71} & \multirow[t]{2}{*}{1.06} & \multirow[t]{2}{*}{-0.99} & HORVU1Hr1G076940.1 & $\begin{array}{l}\text { Nucleotide-diphospho-sugar } \\
\text { transferase family }\end{array}$ & - \\
\hline & & & & HORVU6Hr1G005350.2 & GPI mannosyltransferase 3 & - \\
\hline ata-miR167a-5p & -0.63 & -0.84 & -0.10 & HORVU2Hr1G121110.32 & ARF6 & + \\
\hline ata-miR167b-3p & -0.92 & 1.17 & 0.13 & HORVU1Hr1G075520.2 & Jacalin-related lectin 3 & - \\
\hline \multirow{2}{*}{ ata-miR167b-5p } & \multirow{2}{*}{0.58} & -0.26 & -0.33 & HORVU2Hr1G059280.1 & SWI/SNF complex subunit SWI3C & - \\
\hline & & & & HORVU2Hr1G059130.1 & SWI/SNF complex subunit SWI3C & - \\
\hline tae-miR167c-5p & 0.64 & 1.20 & 0.20 & HORVU1Hr1G077630.2 & $\begin{array}{l}\text { Ubiquitin carboxyl-terminal } \\
\text { hydrolase } 25\end{array}$ & - \\
\hline & & & & HORVU2Hr1G059280.1 & SWI/SNF complex subunit SWI3C & - \\
\hline & & & & HORVU2Hr1G059130.1 & SWI/SNF complex subunit SWI3C & - \\
\hline
\end{tabular}


Table 1. Cont.

\begin{tabular}{|c|c|c|c|c|c|c|}
\hline miRNA Name & $A 1^{a}$ & $\mathrm{Cd}^{\mathrm{b}}$ & Salt ${ }^{c}$ & Target Rranscript & Annotation & $\begin{array}{l}\text { Degradome } \\
\text { Detection }\end{array}$ \\
\hline ata-miR167f-3p & 0.29 & 1.69 & 1.79 & HORVU4Hr1G016990.3 & Cysteine desulfurase & - \\
\hline \multirow[t]{2}{*}{ hvu-miR168-3p } & -0.71 & 0.19 & -0.68 & HORVU5Hr1G037570.4 & Receptor-like protein kinase & - \\
\hline & & & & HORVU4Hr1G031620.1 & 14-3-3 protein beta/alpha-A & - \\
\hline \multirow[t]{2}{*}{ hvu-miR168-5p } & -0.55 & -0.16 & -1.02 & HORVU1Hr1G055570.4 & $\begin{array}{l}\text { WD repeat-containing protein } \\
\text { WRAP73 }\end{array}$ & + \\
\hline & & & & HORVU2Hr1G105050.1 & $\begin{array}{c}\text { Protein of unknown function } \\
\text { (DUF581) }\end{array}$ & + \\
\hline ata-miR169a-3p & 0.58 & -2.90 & -6.21 & HORVU4Hr1G087430.2 & Unknown & - \\
\hline \multirow[t]{5}{*}{ ata-miR169c-5p } & -0.37 & -2.27 & $-\infty$ & HORVU5Hr1G092700.17 & NF-YA10 & + \\
\hline & & & & HORVU4Hr1G075830.4 & NF-YA3 & + \\
\hline & & & & HORVU6Hr1G081080.12 & NF-YA5 & + \\
\hline & & & & HORVU2Hr1G032130.27 & NF-YA5 & + \\
\hline & & & & HORVU2Hr1G032130.6 & NF-YA5 & + \\
\hline \multirow[t]{5}{*}{ ata-miR169i-5p } & 0.42 & -2.04 & -2.89 & HORVU5Hr1G092700.17 & NF-YA10 & + \\
\hline & & & & HORVU4Hr1G075830.4 & NF-YA3 & + \\
\hline & & & & HORVU6Hr1G081080.12 & NF-YA5 & + \\
\hline & & & & HORVU2Hr1G032130.27 & NF-YA5 & + \\
\hline & & & & HORVU2Hr1G032130.6 & NF-YA5 & + \\
\hline \multirow[t]{2}{*}{ hvu-miR171-3p } & 0.28 & 0.72 & -1.31 & HORVU6Hr1G063650.1 & GRAS & + \\
\hline & & & & HORVU1Hr1G053510.1 & GRAS & + \\
\hline ata-miR171a-3p & -0.36 & 0.09 & -1.40 & HORVU4Hr1G061310.1 & GRAS & + \\
\hline ata-miR171a-5p & -1.42 & 0.62 & -1.08 & HORVU2Hr1G076620.7 & T-complex protein 11 & + \\
\hline \multirow[t]{2}{*}{ ata-miR172b-3p } & -0.63 & -0.10 & -0.17 & HORVU5Hr1G112440.1 & Ethylene-responsive TF10 & + \\
\hline & & & & HORVU1Hr1G011800.24 & AP2-like ethylene-responsive TF & + \\
\hline \multirow[t]{2}{*}{ ata-miR172b-5p } & -0.19 & -1.45 & -0.03 & HORVU7Hr1G106280.1 & ARF6 & + \\
\hline & & & & HORVU6Hr1G088570.2 & Clathrin interactor EPSIN 2 & + \\
\hline \multirow[t]{4}{*}{ ata-miR390-5p } & -1.86 & 0.10 & 0.23 & HORVU7Hr1G007520.1 & LRR-RLK & - \\
\hline & & & & HORVU1Hr1G043790.1 & LRR-RLK & - \\
\hline & & & & HORVU2Hr1G091840.16 & RLK2 & - \\
\hline & & & & HORVU2Hr1G124010.6 & RLK & - \\
\hline \multirow[t]{2}{*}{ ata-miR393-5p } & -0.16 & 1.02 & 0.03 & HORVU2Hr1G070800.3 & HvAFB & + \\
\hline & & & & HORVU1Hr1G021550.4 & HvTIR1 & + \\
\hline \multirow[t]{2}{*}{ ata-miR394-5p } & -1.18 & 0.83 & -0.63 & HORVU1Hr1G043940.3 & Protein TIC110, chloroplastic & + \\
\hline & & & & HORVU6Hr1G018370.1 & Calnexin 1 & + \\
\hline \multirow[t]{3}{*}{ ata-miR396e-5p } & 0.51 & 0.62 & -1.36 & HORVU7Hr1G008680.14 & GRF5 & + \\
\hline & & & & HORVU4Hr1G010080.6 & GRF6 & + \\
\hline & & & & HORVU4Hr1G003440.12 & GRF9 & + \\
\hline \multirow[t]{2}{*}{ ata-miR1432-5p } & -1.56 & 0.00 & 0.84 & HORVU1Hr1G094160.1 & Calmodulin like 43 & + \\
\hline & & & & HORVU5Hr1G111520.1 & $\begin{array}{c}\text { EF hand calcium-binding } \\
\text { protein family }\end{array}$ & + \\
\hline \multirow[t]{2}{*}{ tae-MIR9662a-5p } & -0.38 & 1.16 & 0.63 & HORVU5Hr1G123930.2 & $\begin{array}{c}\text { Beta-fructofuranosidase, insoluble } \\
\text { isoenzyme } 3\end{array}$ & - \\
\hline & & & & HORVU2Hr1G100080.7 & Protein strawberry notch homolog 1 & - \\
\hline
\end{tabular}

${ }^{\mathrm{a}} \mathrm{Al},{ }^{\mathrm{b}} \mathrm{Cd}$ and ${ }^{\mathrm{c}}$ Salt represent the fold-changes between different treatments (Al, Cd and salt stresses) and their control-normalized reads. This was calculated using the formula: fold change $=\log 2$ (stress reads/control reads). $-\infty$ indicates that miRNA expression was not detected in Golden Promise under salt treatment. ${ }^{\mathrm{d}}$ Degradome detection indicates that the target genes of miRNAs were either detected $(+)$ or not (-) in the degradome sequencing results. The "MIR" in the miRNA name means that the miRNA belongs to new member of known miRNAs.

\subsection{Characterization of Target Genes for miRNAs}

Putative targets for 290 miRNAs were detected via degradome analysis and bioinformatics prediction (Table S1). As a result, 136 miRNAs were found to be associated with 213 target genes based on bioinformatics predictions, and other $154 \mathrm{miRNAs}$ were related to 287 targets based on degradome analysis (Table S1). Interestingly, many target genes were transcription factors, suggesting their essential roles in regulatory networks under abiotic stress responses. For example, TCP family transcription factor 4 (TCP4) was negatively targeted by osa-miR319a-3p.2-3p, which was upregulated under $\mathrm{Cd}$ and salt stresses. In addition, ata-miR167a-5p was downregulated under $\mathrm{Al}$ and $\mathrm{Cd}$ stresses, and could regulate Auxin response factor 6 (ARF6). Furthermore, a number of target genes encoded receptor kinase and calmodulin, such as hvu-MIR159a-5p-mediated Mitogen-activated Protein Kinase 16 (MPK16) and ata-miR1432-5p-regulated Calmodulin like 43 (CML43), as well as EF hand calcium-binding protein (Table S1). 


\subsection{GO Analysis of Target Genes Regulated by Differently Expressed miRNAs}

A total of 70 putative target transcripts were found for 31 differently expressed miRNAs under three stresses. Among these, 56 target genes were associated with GO analysis in three ontologies. In terms of biological processes, two enriched categories-transcription (DNA-templated) and regulation of transcription (DNA-templated)-occupied the largest components under all three stresses (Figure 4). As for molecular function, transcription factor activity (sequence-specific DNA binding) and DNA binding were most dominant under various stresses. For cellular components, most of the target genes were localized in the nucleus. Obviously, the current results indicate that miRNAs play important roles in the regulatory network of $\mathrm{Al}, \mathrm{Cd}$ and salt stress responses, mainly via the modulation of the target transcription factors.

(a)

(b)

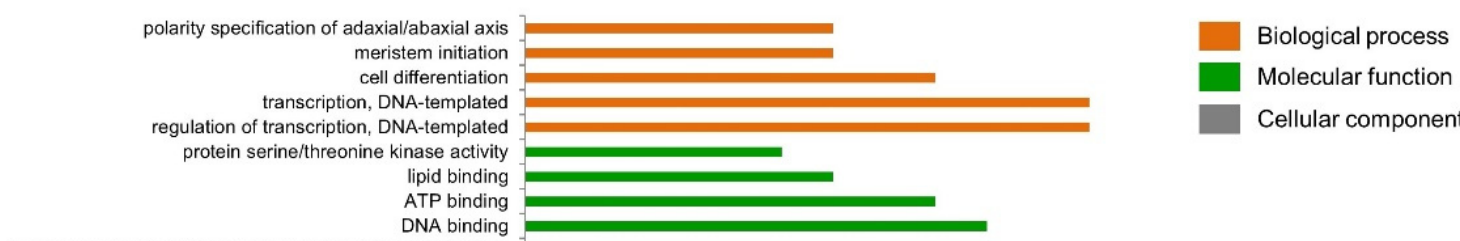

(c)

ranscription factor activity, sequence-specific DNA binding plasmodesma cytoplasm
integral component of membrane
plasma membrane

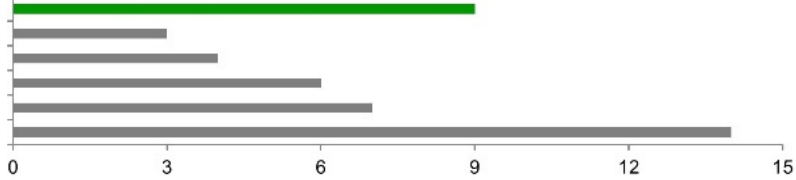

$$
\text { nucleus }
$$

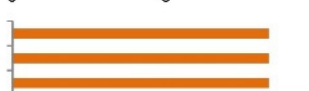

(1)

15
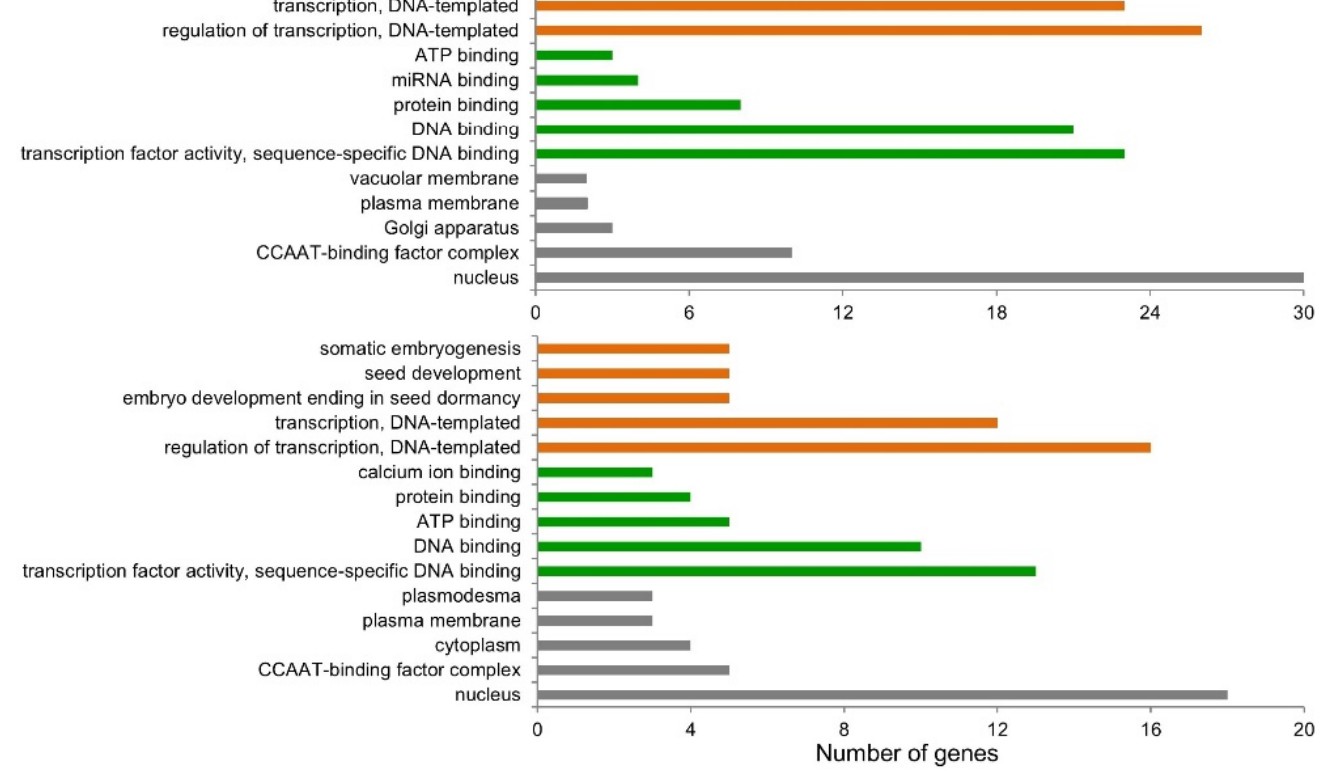

Figure 4. Gene ontology analysis of the putative target genes for 31 differently expressed miRNAs. The categorization of putative targets for miRNAs responsive to $\mathrm{Al}(\mathbf{a}), \mathrm{Cd}(\mathbf{b})$ and salt (c) stress was performed according to biological processes, molecular functions and cellular components.

\section{Discussion}

The physiological and molecular mechanisms of tolerance to various abiotic stresses have been intensively investigated in barley [23-25]. However, there are few reports focusing on the miRNA-mediated networks involved in abiotic stress tolerance. In the present study, 525 miRNAs were identified in barley roots exposed to three stresses (Figure 2a). Among these, 246 miRNAs could be classified into 47 known miRNA families (Figure 3). The analysis of miRNA expression profiles showed that 31 miRNAs were dramatically 
responsive to one, two or three stresses (Table 1 and Figure S1). Furthermore, GO analysis showed that the majority of targets for these miRNAs were transcription factors (Figure 4). Based on the obtained results, we proposed a putative model of miRNA-involved regulatory networks for $\mathrm{Al}, \mathrm{Cd}$ and salt stress responses in barley roots (Figure 5).

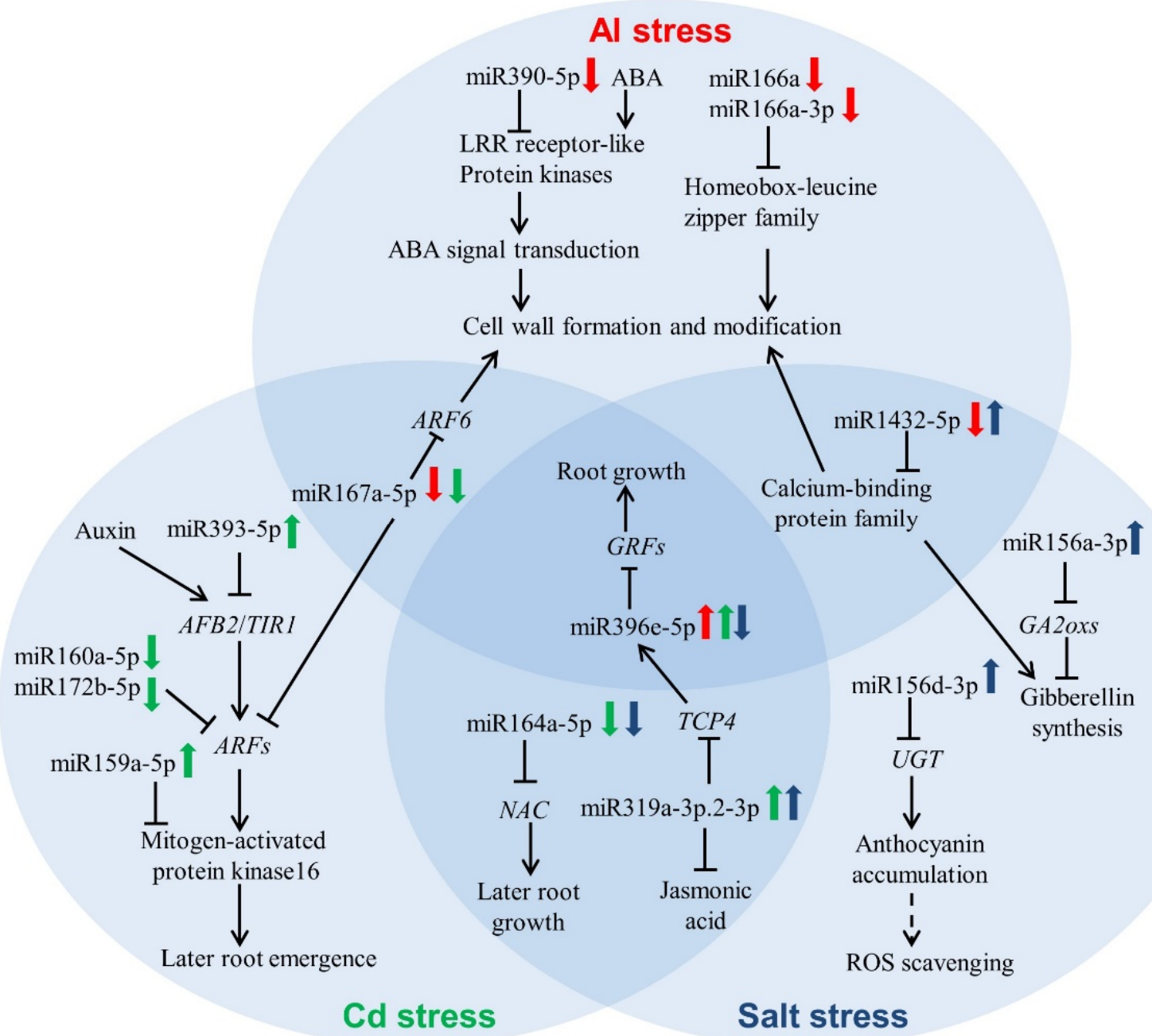

Figure 5. A proposed model of miRNAs involved in $\mathrm{Al}, \mathrm{Cd}$ and salt responses in barley roots. Downregulation of miR390-5p, miR166a and miR166a-3p promotes the process of cell wall formation and modification, thus alleviating Al detoxification. Upregulation of miR393-5p and miR159-5p can repress later root emergence through controlling the module of the auxin signaling pathway combined with MPK under Cd conditions. To alleviate root inhibition, miR160a-5p and miR172b-5p are significantly downregulated, thus increasing the expression of ARFs. Two miR156 family members, miR156a-3p and miR156d-3p, are downregulated, probably leading to reduced ROS scavenging and enhanced gibberellin synthesis after salt treatment. Contrary to $\mathrm{Al}$ and $\mathrm{Cd}$ treatments, repressed miR396e-5p under salt conditions promotes root growth through the accumulation of GRFs.

\section{1. miRNAs Specifically Responding to Al Stress}

In this study, hvu-miR166a and ata-miR166a-3p were downregulated only under $\mathrm{Al}$ stress, which targeted the transcripts of homeobox leucine zipper family genes (Table 1 and Figure S1). HD-Zip IIIs (a group of homeobox transcription factors) were involved in many developmental processes, such as lateral root growth and shoot meristem formation in Arabidopsis [26,27]. Moreover, miR166-mediated cleavage of HD-Zip III was involved in the tolerance to abiotic stresses such as drought in rice [28]. The expression of downstream genes contributing to cell wall formation was altered in the miR166 knockdown lines of rice [28]. The root cell wall $(\mathrm{CW})$ was recognized as the major target cell component of $\mathrm{Al}$ 
toxicity and accumulated more than $90 \%$ of absorbed Al [4]. Therefore, it may be assumed that hvu-miR166a and ata-miR166a-3p play an important role in copying with Al stress through regulating the genes relevant to cell wall formation and modification in barley.

In addition, the expression of ata-miR390-5p was also specifically repressed under $\mathrm{Al}$ stress in barley roots, similarly with that observed in Medicago truncatula [29]. miR390 targeted the genes encoding Leucine-rich repeat receptor-like protein kinases (LRR-RLKs), which acted as receptors of hormones such as abscisic acid (ABA), which are crucial in the transduction of plant environmental signals [30,31]. As one of the topmost transcription factors in ABA signaling transduction pathways, ABI5 positively participated in the Al stress response in Arabidopsis and rice beans (Vigna umbellate) through regulating a series of downstream genes associated with cell wall structure and modification [32]. It was also found that ABA content was increased in barley roots exposed to Al stress [32-34]. Therefore, it may be suggested that miR390 is involved in Al stress tolerance by mediating ABA signal transduction pathways associated with cell wall modification (Figure 5).

\section{2. miRNAs Specifically Responding to Cd Stress}

The root elongation of Arabidopsis was notably reduced under Cd stress, but lateral root formation was significantly promoted [35]. Meanwhile, $\mathrm{Cd}$ stress reduced the endogenous auxin level and the induced toxicity could be alleviated by supplying exogenous auxin in Arabidopsis by stimulating the synthesis of hemicellulose 1 and increasing the cadmium fixation capacity of root cell walls $[35,36]$. In this study, ata-miR393-5p was up-regulated after $\mathrm{Cd}$ exposure, which negatively regulated two auxin receptor genes, HvTIR1 and HvAFB, resulting in changes of downstream auxin response factor (ARF) family members in the auxin signaling pathway [16]. ata-miR160a-5p and ata-miR172b-5p were both downregulated under Cd stress in barley roots, and their targets were referred to $A R F$ genes through degradome sequencing analysis (Table 1 and Figure S1). Recently, it was shown that ARF7 was firstly activated by auxin signaling, and then modulated the MPK3/MPK6 cascade, hence promoting the expression of cell wall remodeling genes associated with pectin degradation and cell wall separation, consequently leading to lateral root emergence [37]. In barley, hvu-MIR159a-5p displayed a higher expression level under Cd stress, targeting the gene HORVU1Hr1G088510.1 encoding Mitogen-activated protein kinase 16 (Table 1 and Figure S1). The signaling modules of MPK cascades are highly conserved in eukaryotes [38]. Thus, it may be assumed that the auxin signaling pathway, combined with MPK modules, is involved in the lateral root emergence of barley in response to Cd stress [35-37].

\section{3. miRNAs Specifically Responding to Salt Stress}

Salt stress positively regulated the GA 2-oxidase family gene GA2ox7, leading to the reduction of bioactive gibberellin (GA) [39]. Moreover, OsGA2ox5 over-expressing rice lines showed higher resistance to salinity than wild-type plants [40]. In this study, ata-miR156a$3 p$ was obviously upregulated under salt stress and its target gene HORVU3Hr1G072810.1 encoded Gibberellin 2-oxidase. Moreover, degradome sequencing analysis showed that another miR156 family member, ata-miR156d-3p, was upregulated under salt stress, targeting the gene encoding UDP-glycosyltransferase (UGT) superfamily protein (Table 1 and Figure S1). Two glycosyltransferase genes, AtUGT79B2 and AtUGT79B3, were proven to be positive regulators of drought, low-temperature and as salt stresses by promoting anthocyanin accumulation [41]. Anthocyanin could serve as an antioxidant, scavenging ROS in response to stresses [42]. Obviously, these two miR156 members are involved in salt stress responses, regulating gibberellin and anthocyanin accumulation in barley, respectively (Figure 5).

\section{4. miRNAs Responding to Various Abiotic Stresses}

A number of miRNAs responding to two or three stresses were also identified. The miRNA ata-miR167a-5p was downregulated under either $\mathrm{Al}$ or $\mathrm{Cd}$ exposure, and its target 
gene was ARF6 based on degradome analysis. The Arabidopsis double mutant of arf10/16 showed significant enhancement in Al tolerance due to modification of the cell wall [43]. Thus, the miR167a/ARF6 module is probably associated with Al tolerance by modifying the barley cell wall, and Cd stress by activating the aforementioned auxin signaling pathway combined with MPK signaling modules (Figure 5).

Moreover, ata-miR1432-5p, targeting the genes encoding calmodulin-like 43 and EF hand calcium-binding protein, responded to both $\mathrm{Al}$ and salt stresses in the different expression patterns. Calcium is recognized as a second messenger and its sensor proteins contain calmodulin (CaM) and calcineurin B-like protein (CBL) [44]. The cbl1 Arabidopsis mutant was more sensitive to Al stress, partially due to differently expressed genes associated with cell wall modification [45]. Furthermore, reduced GA content was also observed in cbl1 mutants [46]. Hence, it may be assumed that the miR1432/calcium-binding protein module alleviates Al toxicity by modifying the cell wall and enhances salt tolerance through reducing GA accumulation (Figure 5).

Lateral root development could be promoted by miRNA164-directed cleavage of NAC1 in maize [47]. In the current study, ata-miR164a-5p was downregulated under either $\mathrm{Cd}$ or salt stress. Its target gene, HORVU2Hr1G080460.8, encoded the NAC domain-containing protein, implying the similar regulation of lateral root growth in barley. Unlike ata-miR164a5p, osa-miR319a-3p.2-3p was upregulated under these two stresses. It was reported that over-expression of miR319 could reduce the level of jasmonic acid in tomato [48]. Moreover, jasmonic acid treatment enhanced salt tolerance in Brassica napus [49]. Arabidopsis mutants with functional deficiency in terms of jasmonic acid synthesis showed more sensitivity to $\mathrm{Cd}$ than the wild-type plant due to elevated expression of the genes associated with $\mathrm{Cd}$ uptake [50]. On the other hand, miR319-mediated TCP4 could positively regulate miR396, which was upregulated under $\mathrm{Al}$ and $\mathrm{Cd}$ exposure but downregulated under salt stress. miR396 over-expressing transgenic plants exhibited the reduced expression of its targets, growth-regulating factors (GRFs), resulting in suppressed root growth [51]. Therefore, it can be hypothesized that miR319 and miR396 participate in $\mathrm{Al}, \mathrm{Cd}$ and salt tolerance through regulating root growth, whereas miR319 is also involved in $\mathrm{Cd}$ and salt tolerance by modulating jasmonic acid synthesis in barley (Figure 5).

\section{Materials and Methods}

\subsection{Plant Culture and Stress Treatment}

To observe the root growth under different stresses, the seeds of barley cultivar Golden Promise were disinfected with $3 \% \mathrm{H}_{2} \mathrm{O}_{2}$ for $20 \mathrm{~min}$, washed with floating tap water and soaked in deionized water for $2 \mathrm{~h}$. Then seeds were transferred to wet filter papers in germination boxes in a dark environment $\left(22 / 18^{\circ} \mathrm{C}\right.$, day/night). On the third day, light was supplied. Parts of the seedlings were transferred into $1 \mathrm{mM} \mathrm{CaCl} 2$ solution ( $\mathrm{pH} 4.5)$ containing $10 \mu \mathrm{M} \mathrm{AlCl} 3$ and the solution was renewed daily. The remaining seedlings were grown in germination boxes for 7 days, and then cultured in the aerated one-fifth Hoagland solution ( $\mathrm{pH}$ 6.0, renewed every 3 days) for 5 days. Finally, twelve-day-old seedlings were treated with one-fifth Hoagland solution containing $200 \mathrm{mM} \mathrm{NaCl}$ and $5 \mu \mathrm{M} \mathrm{CdCl}_{2}$, respectively. The solution without $\mathrm{AlCl}_{3}, \mathrm{NaCl}$ or $\mathrm{CdCl}_{2}$ additions was used for controls. After stress exposure for 10 days, the length of the longest root was measured.

To generate miRNA data, seeds were disinfected and germinated following the aforementioned method. After 7 days' germination, seedlings were transferred into 5-L plastic containers with aerated one-fifth Hoagland solution. Salt treatment was initiated at 7 days after transplanting by adding $\mathrm{NaCl}$ at a rate of $100 \mathrm{mM}$ per day, to reach a final concentration of $200 \mathrm{mM}$ in the solution. After 10 days of salt treatment, roots from salt-treated and control conditions were harvested. Twelve-day-old seedlings were treated with one-fifth Hoagland solution containing $5 \mu \mathrm{M} \mathrm{CdCl}_{2}$ and root samples were collected after 10 days. Meanwhile, twelve-day-old seedlings were exposed to $1 \mathrm{mM} \mathrm{CaCl}$ solution ( $\mathrm{pH} 4.5$ ) containing $10 \mu \mathrm{M} \mathrm{AlCl}$. The $\mathrm{CaCl}_{2}$ solution ( $\mathrm{pH}$ 4.5) without $\mathrm{Al}$ was considered as the control. The roots under control and Al-treated conditions were harvested after $24 \mathrm{~h}$ and 
frozen immediately in liquid nitrogen, then stored at $-80{ }^{\circ} \mathrm{C}$. All of the root samples, including three treatments and corresponding controls, were finally used for small RNA and degradome sequencing analysis.

\subsection{Construction of Small RNA and Degradome Libraries}

In addition to these 12 small RNA libraries (root tissue of Golden Promise in controls and three stresses with two biological replicates), three degradome libraries (three stresses and their corresponding controls were mixed well, respectively) were also constructed to obtain the targets of miRNAs. Trizol reagent (Invitrogen, Carlsbad, CA, USA) was used to extract the total RNA of samples and then methods described previously were performed for the construction of two kinds of libraries [22,52]. To construct small RNA libraries, TruSeq Small RNA Sample Prep Kit (Illumina, San Diego, CA, USA) was used. Adenylated single-stranded $3^{\prime}$ and $5^{\prime}$ adapters were ligated to small RNA respectively with the use of T4 RNA ligase 2. The reverse transcription reaction was performed to synthesize the first-strand cDNA with subsequent PCR amplification. Finally, PCR products with the length of $140-160 \mathrm{bp}$ were collected from $6 \%$ polyacrylamide Tris-borate-EDTA gel. To prepare the degradome library, the methods described by Ma et al. [52] were performed with some modifications. The poly(A) RNA was used as the input RNA and annealed with biotinylated random primers. Strapavidin capture of RNA fragments and $5^{\prime}$ adaptor ligation to RNAs containing $5^{\prime}$-monophosphates were carried out. Then reverse transcription and PCR amplification were performed. Two kinds of libraries were singleend sequenced (50 bp) on an Illumina Hiseq2500 platform (Illumina, San Diego, CA, USA).

\subsection{Data Processing of Sequencing}

The raw data of high-throughput small RNA sequencing for the root samples from $\mathrm{Al}$, $\mathrm{Cd}$ and salt stresses and their controls were processed using the ACGT101-miR program (LC Sciences, Houston, TX, USA) to remove adapters and sequences without typical miRNA features. Then, sequences were mapped to mRNA (http:/ / plants.ensembl.org/ Hordeum_vulgare/Info/Index, accessed on 1 January 2021), Repbase (http:/ /www.girinst. org/repbase, accessed on 1 January 2021) and RFam (http://rfam.janelia.org, accessed on 1 January 2021) databases to eliminate mRNA, prototypic sequences representing repetitive DNA (repeats) and common non-coding RNA families such as rRNA and snRNA, excepting miRNAs. Subsequently, the remaining clean sequences with 18-25 nucleotides were matched to miRBase (version 21) through a BLAST search. The miRNAs that were perfectly or imperfectly (within two mismatches) mapped to mature miRNAs of plant species were recognized as known miRNAs. The miRNAs which did not match to miRNAs but successfully mapped to the opposite arm of known precursors were defined as new members of known miRNAs. Potential candidate miRNAs could not be matched to known mature miRNAs or precursors, and generally showed low expression. Furthermore, the genomic location of each identified miRNA was determined when the matched premiRNAs were BLASTed against the barley reference genome.

Bioinformatics analysis was conducted using TargetFinder to identify miRNA binding sites. Moreover, degradome libraries were constructed to obtain the targets of miRNAs. Pipeline (version 1.5; Illumina) was used to filter raw sequencing reads and then sequencing data were analyzed by the software package CleaveLand3.0 [53]. The sequences of degradome libraries were BLASTed against the barley mRNA database in IPK. The links of all databases listed in this study were shown in our previous research [21]. In addition, GO annotation analysis was carried out using Blast2GO software (https: / /www.blast2go.com/, accessed on 1 February 2021) based on mRNA sequences.

\subsection{Characterization of miRNAs Responding to Al, Cd and Salt Stresses}

The miRNAs in response to $\mathrm{Al}, \mathrm{Cd}$ and salt stresses were expected to meet the criteria described by $\mathrm{Wu}$ et al. [21]. Moreover, miRNAs were detected in all libraries and at least one normalized readcount was greater than 100 in these three stress treatments or controls. 
The fold change of normalized reads between stress treatment and control samples was calculated using the formula: fold change $=\log _{2}$ (stress reads $/$ control reads). The miRNAs were defined as upregulated if fold change $\geq 0.5$, and downregulated if fold change $\leq-0.5$.

\section{Conclusions}

In the current study, 31 miRNAs and their targets were identified in the roots of barley seedlings exposed to $\mathrm{Al}, \mathrm{Cd}$ and salt stresses. Among these, 12 miRNAs were specifically responsive to only one stress, such as miR390 responding to Al stress, miR393 responding to $\mathrm{Cd}$ stress and miR156d responding to salt stress, whereas there were several miRNAs, such as miR169, miR396 and miR1432, which responded to multiple stresses. These miRNAs and their target genes participated in the regulation of root growth and development via various signal transduction pathways under abiotic stresses. A model of miRNAs responding to $\mathrm{Al}, \mathrm{Cd}$ and salt stresses was proposed, which may provide an overall understanding of the mechanisms of miRNAs in regulating stress tolerance in barley.

Supplementary Materials: The following are available online at https:/ /www.mdpi.com/article/ 10.3390/plants10122754/s1. Figure S1: Heatmap of 31 miRNAs in response to $\mathrm{Al}, \mathrm{Cd}$ and salt stresses. Table S1: Detailed information of miRNAs identified in roots of barley.

Author Contributions: Conceptualization, L.K. and L.W.; methodology, L.K., J.Y., Q.S. and L.W.; formal analysis, L.K. and L.W.; investigation, L.F.; resources, L.K., J.Y. and L.W.; writing-original draft preparation, L.K. and L.W.; writing-review and editing, L.K. and L.W.; visualization, L.F. All authors have read and agreed to the published version of the manuscript.

Funding: This research was supported by Natural Science Foundation of China (32101669 and 31620103912), China Agriculture Research System (CARS-05) and Jiangsu Collaborative Innovation Center for Modern Crop Production.

Institutional Review Board Statement: Not applicable.

Informed Consent Statement: Not applicable.

Data Availability Statement: The raw data are available at NCBI database with the BioProject accession numbers PRJNA481620, PRJNA485436 and PRJNA507337.

Acknowledgments: The authors are grateful to Jiming Xu from Zhejiang University for the technical support.

Conflicts of Interest: The authors declare that they have no competing interests.

\section{References}

1. FAO. Status of Research and Application of Crop Biotechnologies in Developing Countries. 2004. Available online: https: //www.fao.org/3/y5800e/Y5800E00.htm (accessed on 31 August 2004).

2. Kochian, L.V.; Pineros, M.A.; Liu, J.; Magalhaes, J.V. Plant adaptation to acid soils: The molecular basis for crop aluminum resistance. Annu. Rev. Plant Biol. 2015, 66, 571-598. [CrossRef]

3. Dai, Z.; Zhang, X.; Tang, C.; Muhammad, N.; Wu, J.; Brookes, P.C.; Xu, J. Potential role of biochars in decreasing soil acidificationA critical review. Sci. Total Environ. 2017, 581, 601-611. [CrossRef]

4. Ma, J.F. Syndrome of aluminum toxicity and diversity of aluminum resistance in higher plants. Int. Rev. Cytol. 2007, 264, 225-252. [PubMed]

5. Rai, P.K.; Lee, S.S.; Zhang, M.; Tsang, Y.F.; Kim, K.-H. Heavy metals in food crops: Health risks, fate, mechanisms, and management. Environ. Int. 2019, 125, 365-385. [CrossRef]

6. Rodriguez-Serrano, M.; Romero Puertas, M.C.; Pazmino, D.M.; Testillano, P.S.; Risueno, M.C.; del Rio, L.A.; Sandalio, L.M. Cellular response of pea plants to cadmium toxicity: Cross talk between reactive oxygen species, nitric oxide, and calcium. Plant Physiol. 2009, 150, 229-243. [CrossRef] [PubMed]

7. Rengasamy, P. Soil processes affecting crop production in salt-affected soils. Funct. Plant Biol. 2010, 37, 613-620. [CrossRef]

8. Munns, R. Genes and salt tolerance: Bringing them together. New Phytol. 2005, 167, 645-663. [CrossRef] [PubMed]

9. Qiu, L.; Wu, D.Z.; Ali, S.; Cai, S.G.; Dai, F.; Jin, X.L.; Wu, F.B.; Zhang, G.P. Evaluation of salinity tolerance and analysis of allelic function of HvHKT1 and HvHKT2 in Tibetan wild barley. Theor. Appl. Genet. 2011, 122, 695-703. [CrossRef] [PubMed]

10. Cai, S.G.; Wu, D.Z.; Jabeen, Z.; Huang, Y.Q.; Huang, Y.C.; Zhang, G.P. Genome-wide association analysis of aluminum tolerance in cultivated and Tibetan wild barley. PLoS ONE 2013, 8, e69776. [CrossRef] 
11. Wu, D.Z.; Sato, K.; Ma, J.F. Genome-wide association mapping of cadmium accumulation in different organs of barley. New Phytol. 2015, 208, 817-829. [CrossRef] [PubMed]

12. Sun, G.L. MicroRNAs and their diverse functions in plants. Plant Mol. Biol. 2012, 80, 17-36. [CrossRef] [PubMed]

13. Bian, H.W.; Xie, Y.K.; Guo, F.; Han, N.; Ma, S.Y.; Zeng, Z.H.; Wang, J.H.; Yang, Y.N.; Zhu, M.Y. Distinctive expression patterns and roles of the miRNA393/TIR1 homolog module in regulating flag leaf inclination and primary and crown root growth in rice (Oryza sativa). New Phytol. 2012, 196, 149-161. [CrossRef] [PubMed]

14. Houston, K.; McKim, S.M.; Comadran, J.; Bonar, N.; Druka, I.; Uzrek, N.; Cirillo, E.; Guzy-Wrobelska, J.; Collins, N.C.; Halpin, C.; et al. Variation in the interaction between alleles of HvAPETALA2 and microRNA172 determines the density of grains on the barley inflorescence. Proc. Natl. Acad. Sci. USA 2013, 110, 16675-16680. [CrossRef] [PubMed]

15. Nair, S.K.; Wang, N.; Turuspekov, Y.; Pourkheirandish, M.; Sinsuwongwat, S.; Chen, G.; Sameri, M.; Tagiri, A.; Honda, I.; Watanabe, Y.; et al. Cleistogamous flowering in barley arises from the suppression of microRNA-guided HvAP2 mRNA cleavage. Proc. Natl. Acad. Sci. USA 2010, 107, 490-495. [CrossRef]

16. Xia, K.F.; Wang, R.; Ou, X.J.; Fang, Z.M.; Tian, C.G.; Duan, J.; Wang, Y.Q.; Zhang, M.Y. OsTIR1 and OsAFB2 downregulation via osmiR393 overexpression leads to more tillers, early flowering and less tolerance to salt and drought in rice. PLoS ONE 2012, 7, e30039. [CrossRef]

17. Gao, P.; Bai, X.; Yang, L.; Lv, D.; Li, Y.; Cai, H.; Ji, W.; Guo, D.; Zhu, Y. Over-expression of osa-MIR396c decreases salt and alkali stress tolerance. Planta 2010, 231, 991-1001. [CrossRef]

18. Bukhari, S.A.H.; Shang, S.H.; Zhang, M.; Zheng, W.T.; Zhang, G.P.; Wang, T.Z.; Shamsi, I.H.; Wu, F.B. Genome-wide identification of chromium stress-responsive microRNAs and their target genes in tobacco (Nicotiana tabacum) roots. Environ. Toxicol. Chem. 2015, 34, 2573-2582. [CrossRef]

19. Ding, Y.F.; Gong, S.H.; Wang, Y.; Wang, F.J.; Bao, H.X.G.D.L.; Sun, J.W.; Cai, C.; Yi, K.K.; Chen, Z.X.; Zhu, C. MicroRNA166 modulates cadmium tolerance and accumulation in rice. Plant Physiol. 2018, 177, 1691-1703. [CrossRef]

20. Yu, J.H.; Wu, L.Y.; Fu, L.B.; Shen, Q.F.; Kuang, L.H.; Wu, D.Z.; Zhang, G.P. Genotypic difference of cadmium tolerance and the associated microRNAs in wild and cultivated barley. Plant Growth Regul. 2019, 87, 389-401. [CrossRef]

21. Wu, L.Y.; Yu, J.H.; Shen, Q.F.; Huang, L.; Wu, D.Z.; Zhang, G.P. Identification of microRNAs in response to aluminum stress in the roots of Tibetan wild barley and cultivated barley. BMC Genom. 2018, 19, 560. [CrossRef]

22. Kuang, L.H.; Shen, Q.F.; Wu, L.Y.; Yu, J.H.; Fu, L.B.; Wu, D.Z.; Zhang, G.P. Identification of microRNAs responding to salt stress in barley by high-throughput sequencing and degradome analysis. Environ. Exp. Bot. 2019, 160, 59-70. [CrossRef]

23. Huang, L.; Kuang, L.; Wu, L.; Shen, Q.; Han, Y.; Jiang, L.; Wu, D.; Zhang, G. The HKT transporter HvHKT1;5 negatively regulates salt tolerance. Plant Physiol. 2020, 182, 584-596. [CrossRef] [PubMed]

24. Wu, D.; Yamaji, N.; Yamane, M.; Kashino-Fujii, M.; Sato, K.; Ma, J.F. The HvNramp5 transporter mediates uptake of cadmium and manganese, but not iron. Plant Physiol. 2016, 172, 1899-1910. [CrossRef]

25. Wu, L.; Guo, Y.; Cai, S.; Kuang, L.; Shen, Q.; Wu, D.; Zhang, G. The zinc finger transcription factor ATF1 regulates aluminum tolerance in barley. J. Exp. Bot. 2020, 71, 6512-6523. [CrossRef] [PubMed]

26. Hawker, N.P.; Bowman, J.L. Roles for class III HD-Zip and KANADI genes in Arabidopsis root development. Plant Physiol. 2004, 135, 2261-2270. [CrossRef]

27. Prigge, M.J.; Otsuga, D.; Alonso, J.M.; Ecker, J.R.; Drews, G.N.; Clark, S.E. Class III homeodomain-leucine zipper gene family members have overlapping, antagonistic, and distinct roles in Arabidopsis development. Plant Cell 2005, 17, 61-76. [CrossRef] [PubMed]

28. Zhang, J.S.; Zhang, H.; Srivastava, A.K.; Pan, Y.J.; Bai, J.J.; Fang, J.J.; Shi, H.Z.; Zhu, J.K. Knock-down of rice microRNA166 confers drought resistance by causing leaf rolling and altering stem xylem development. Plant Physiol. 2018, 176, 2082-2094. [CrossRef]

29. Chen, L.; Wang, T.Z.; Zhao, M.G.; Tian, Q.Y.; Zhang, W.H. Identification of aluminum-responsive microRNAs in Medicago truncatula by genome-wide high-throughput sequencing. Planta 2012, 235, 375-386. [CrossRef]

30. Tichtinsky, G.; Vanoosthuyse, V.; Cock, J.M.; Gaude, T. Making inroads into plant receptor kinase signalling pathways. Trends Plant Sci. 2003, 8, 231-237. [CrossRef]

31. Osakabe, Y.; Maruyama, K.; Seki, M.; Satou, M.; Shinozaki, K.; Yamaguchi Shinozaki, K. Leucine-rich repeat receptor-like kinase1 is a key membrane-bound regulator of abscisic acid early signaling in Arabidopsis. Plant Cell 2005, 17, 1105-1119. [CrossRef]

32. Fan, W.; Xu, J.M.; Wu, P.; Yang, Z.X.; Lou, H.Q.; Chen, W.W.; Jin, J.F.; Zheng, S.J.; Yang, J.L. Alleviation by abscisic acid of Al toxicity in rice bean is not associated with citrate efflux but depends on ABI5-mediated signal transduction pathways. J. Integr. Plant Biol. 2019, 61, 140-154. [CrossRef] [PubMed]

33. Ahmed, I.M.; Nadira, U.A.; Cao, F.; He, X.; Zhang, G.; Wu, F. Physiological and molecular analysis on root growth associated with the tolerance to aluminum and drought individual and combined in Tibetan wild and cultivated barley. Planta 2016, 243, 973-985. [CrossRef]

34. Kopittke, P.M. Role of phytohormones in aluminium rhizotoxicity. Plant Cell Environ. 2016, 39, 2319-2328. [CrossRef]

35. Hu, Y.F.; Zhou, G.; Na, X.F.; Yang, L.; Nan, W.B.; Liu, X.; Zhang, Y.Q.; Li, J.L.; Bi, Y.R. Cadmium interferes with maintenance of auxin homeostasis in Arabidopsis seedlings. J. Plant Physiol. 2013, 170, 965-975. [CrossRef]

36. Zhu, X.F.; Wang, Z.W.; Dong, F.; Lei, G.J.; Shi, Y.Z.; Li, G.X.; Zheng, S.J. Exogenous auxin alleviates cadmium toxicity in Arabidopsis thaliana by stimulating synthesis of hemicellulose 1 and increasing the cadmium fixation capacity of root cell walls. J. Hazard. Mater. 2013, 263, 398-403. [CrossRef] 
37. Zhu, Q.K.; Shao, Y.M.; Ge, S.T.; Zhang, M.M.; Zhang, T.S.; Hu, X.T.; Liu, Y.D.; Walker, J.; Zhang, S.Q.; Xu, J. A MAPK cascade downstream of IDA-HAE/HSL2 ligand-receptor pair in lateral root emergence. Nat. Plants 2019, 5, 414-423. [CrossRef]

38. Enders, T.A.; Frick, E.M.; Strader, L.C. An Arabidopsis kinase cascade influences auxin-responsive cell expansion. Plant J. 2017, 92, 68-81. [CrossRef] [PubMed]

39. Magome, H.; Yamaguchi, S.; Hanada, A.; Kamiya, Y.; Oda, K. The DDF1 transcriptional activator upregulates expression of a gibberellin-deactivating gene, GA2ox7, under high-salinity stress in Arabidopsis. Plant J. 2008, 56, 613-626. [CrossRef]

40. Shan, C.; Mei, Z.L.; Duan, J.L.; Chen, H.Y.; Feng, H.F.; Cai, W.M. OsGA2ox5, a gibberellin metabolism enzyme, is involved in plant growth, the root gravity response and salt stress. PLOS ONE 2014, 9, e87110.

41. Li, P.; Li, Y.J.; Zhang, F.J.; Zhang, G.Z.; Jiang, X.Y.; Yu, H.M.; Hou, B.K. The Arabidopsis UDP-glycosyltransferases UGT79B2 and UGT79B3, contribute to cold, salt and drought stress tolerance via modulating anthocyanin accumulation. Plant J. 2017, 89, 85-103. [CrossRef] [PubMed]

42. Pourcel, L.; Routaboul, J.M.; Cheynier, V.; Lepiniec, L.; Debeaujon, I. Flavonoid oxidation in plants: From biochemical properties to physiological functions. Trends Plant Sci. 2007, 12, 29-36. [CrossRef]

43. Yang, Z.B.; Geng, X.Y.; He, C.M.; Zhang, F.; Wang, R.; Horst, W.J.; Ding, Z.J. TAA1-regulated local auxin biosynthesis in the root-apex transition zone mediates the aluminum-induced inhibition of root growth in Arabidopsis. Plant Cell 2014, 26, 2889-2904. [CrossRef]

44. Yu, Q.Y.; An, L.J.; Li, W.L. The CBL-CIPK network mediates different signaling pathways in plants. Plant Cell Rep. 2014, 33, 203-214. [CrossRef]

45. Ligaba-Osena, A.; Fei, Z.J.; Liu, J.P.; Xu, Y.M.; Shaff, J.; Lee, S.C.; Luan, S.; Kudla, J.; Kochian, L.; Pineros, M. Loss-of-function mutation of the calcium sensor CBL1 increases aluminum sensitivity in Arabidopsis. New Phytol. 2017, 214, 830-841. [CrossRef]

46. Li, Z.Y.; Xu, Z.S.; Chen, Y.; He, G.Y.; Yang, G.X.; Chen, M.; Li, L.C.; Ma, Y.Z. A novel role for Arabidopsis CBL1 in affecting plant responses to glucose and gibberellin during germination and seedling development. PLoS ONE 2013, 8, e56412. [CrossRef]

47. Li, J.; Guo, G.H.; Guo, W.W.; Guo, G.G.; Tong, D.; Ni, Z.F.; Sun, Q.X.; Yao, Y.Y. miRNA164-directed cleavage of ZmNAC1 confers lateral root development in maize (Zea mays L.). BMC Plant Biol. 2012, 12, 220. [CrossRef] [PubMed]

48. Zhao, W.C.; Li, Z.L.; Fan, J.W.; Hu, C.L.; Yang, R.; Qi, X.; Chen, H.; Zhao, F.K.; Wang, S.H. Identification of jasmonic acid-associated microRNAs and characterization of the regulatory roles of the miR319/TCP4 module under root-knot nematode stress in tomato. J. Exp. Bot. 2015, 66, 4653-4667. [CrossRef]

49. Kaur, H.; Sharma, P.; Sirhindi, G. Sugar accumulation and its regulation by jasmonic acid in Brassica napus L. under salt stress. J. Stress Physiol. Biochem. 2013, 9, 53-64.

50. Lei, G.J.; Sun, L.; Sun, Y.; Zhu, X.F.; Li, G.X.; Zheng, S.J. Jasmonic acid alleviates cadmium toxicity in Arabidopsis via suppression of cadmium uptake and translocation. J. Integr. Plant Biol. 2020, 62, 218-227. [CrossRef] [PubMed]

51. Bazin, J.; Khan, G.A.; Combier, J.P.; Bustos-Sanmamed, P.; Manuel Debernardi, J.; Rodriguez, R.; Sorin, C.; Palatnik, J.; Hartmann, C.; Crespi, M.; et al. miR396 affects mycorrhization and root meristem activity in the legume Medicago truncatula. Plant J. 2013, 74, 920-934. [CrossRef]

52. Ma, Z.R.; Coruh, C.; Axtell, M.J. Arabidopsis lyrata small RNAs: Transient MIRNA and small interfering RNA loci within the Arabidopsis genus. Plant Cell 2010, 22, 1090-1103. [CrossRef] [PubMed]

53. Addo-Quaye, C.; Miller, W.; Axtell, M.J. CleaveLand: A pipeline for using degradome data to find cleaved small RNA targets. Bioinformatics 2009, 25, 130-131. [CrossRef] [PubMed] 